\title{
Hydropriming -a useful technique for seed invigoration in okra (Abelmoschus esculentus) and parsley (Petroselinum crispum)
}

\author{
F. A. $\operatorname{Khan}^{1 *}$, S. Narayan ${ }^{2}$, S. A. Bhat ${ }^{1}$, I. Murtuza ${ }^{1}$ and K Hussain ${ }^{2}$ \\ ${ }^{1}$ Division of Post Harvest Technology, SKUAST-Kashmir, Shalimar, Srinagar (J\&K), INDIA \\ ${ }^{2}$ Division of Vegetable Science, SKUAST-Kashmir, Shalimar, Srinagar (J\&K), INDIA \\ *Corresponding author. E- mail: drkhan_387@skuastkashmir.ac.in \\ Received: October 28, 2016; Revised received: April 21, 2017; Accepted: August 22, 2017
}

\begin{abstract}
Seed germinating ability and stand establishment determine the management options in crop production system. Physiological advancement of seeds through priming is a simple and cost-effective method to improve the germinability and stand of any crop. Studies were performed on seed invigoration through hydropriming at the division of PHT, SKUAST-Kashmir during the year 2016 to optimize the hydropriming duration for improved germination and seedling vigour of okra (Pusa sawani) and parsley (curly type). Freshly harvested seeds were soaked in normal water for varying durations (okra- 12,18 and $24 \mathrm{~h}$; parsley- 24,48 and $72 \mathrm{~h}$ ) at $\left(25 \pm 2^{\circ} \mathrm{C}\right)$ and re-dried to original moisture content at room temperature. Fifty seeds of each treatment were cultured in $14.0 \mathrm{~cm}$ Petri dishes lined with 5 layers of moist blotting paper. Observations on various germination parameters were recorded at $\left(25 \pm 2^{\circ} \mathrm{C}\right)$. Priming of okra seeds for $18 \mathrm{~h}$ resulted in highest FGP $(85.7 \%), \mathrm{GE}(66.5 \%)$, GI (36.7), SDB $\left(29.1 \mathrm{mg}\right.$ ) and SVI (2.49) coupled with minimum values of $\mathrm{T}_{50}$ (2.75 day) as well as MGT (2.38 day). However, the highest FGP $(78.7 \%)$, GE $(48.7 \%)$, SDB $(3.13 \mathrm{mg}), \mathrm{GI}(12.8)$ and SVI $(0.25)$ together with minimum $\mathrm{T}_{50}(7.2$ day) and MGT (6.5 day) in parsley was recorded with $24 \mathrm{~h}$ priming duration. As such priming duration of 18 and 24 hours at $25 \pm 2^{\circ} \mathrm{C}$ were found optimal for enhanced and rapid seed germination with vigourous seedlings.
\end{abstract}

Keywords: Hydropriming, Okra, Parsley, Seed germination, Seedling vigour

\section{INTRODUCTION}

Being a rich source of vitamins and other essential nutrients, vegetables play an important role in human diet. They also gave more farm income than other crops. However, uniformity and rapidity of seed germination and emergence are essential to increase quality and profitable yield (Cantliffe, 2003; Duman and Eşiyok, 1998) which can be achieved by using improved seed quality. Okra is a popular vegetable of the world which contains vitamin $\mathrm{A}$ and $\mathrm{C}$ and is a good source of iron and calcium but suffers from poor and uneven seed germination and field emergence (Pandita et al., 2010). Parsley is an important green leafy vegetable of the family Apiaceae and widely used as garnish to boost flavor and look of a dish. It is packed with minerals and vitamins and also recognized as one of the functional food for its unique antioxidants and disease preventing properties. However, its seeds have shorter viable life and also take longer time to germinate, especially under unfavorable environmental conditions (Vural et al., 2000). Seed priming i.e. controlled hydration of seeds by exposing them to low water potential and re-drying, to permit pre-germinative physio-biochemical changes to occur but restrict germination is a known technique for improved seed germination potential under normal as well as stressful environments. The conventional way of seed priming has been to immerse them in an aerated solution of an osmotic material, usually polyethylene glycol (PEG) for a certain period of time and then re-drying to original moisture content. Hydropriming (HP) introduces normal liquid water to seeds in controlled and precise amounts to achieve a desired level of hydration (McDonald, 1999). HP has been proved as a useful technique in many crops for accelerating germination with improved seedling vigour (Huang et al., 2002; Ghassemi-Golezani, et al., 2010; Ogbuehi et al., 2013). However, success of hydropriming depends on priming duration which varied widely from crop to crop (Ghassemi-Golezani, et al., 2010; Khafagy, et al., 2014). Further, information available on priming of vegetable seeds particularly okra and parsley are scanty. Hence the present work has been performed to optimize the priming duration for okra (Pusa sawani) and parsley (curly type) seeds and realize the benefits of hydropriming technique in terms of germination per cent, rapidity and seedling vigour.

\section{MATERIALS ANS METHODS}

The experiments were performed at the Division of Post Harvest Technology, SKUAST-Kashmir, Shalimar (Srinagar) during the year 2016. The seeds of okra (cv. Pusa sawani) and parsley (curly type) were 
obtained from the division of Vegetable Science, SKUAST-Kashmir. Two independent experiments were organized one each for okra and parsley. Approximately 10.0 and $1.0 \mathrm{~g}$ of okra and parsley seeds were hydroprimed by soaking them in ten layers of blotting paper fully saturated with distilled water and kept in a BOD incubator for 12, 18 and 24 hours and 24, 48 and 72 hours, respectively at $25 \pm 2^{\circ} \mathrm{C}$. Dry seeds without priming were taken as control. The seeds were surfaced sterilized in 1:10 (v/v) dilution of commercial hypochlorite bleach for $10 \mathrm{~min}$ and rinsed several times with distilled water. Fifty seeds of each treatment were cultured in $14.0 \mathrm{~cm}$ Petri dishes lined with 5 layers of moist blotting paper. The experiment was set in an incubator $\left(25 \pm 2^{\circ} \mathrm{C}\right)$ following randomized block design (CRD) with four replications. Seed germination was recorded on daily basis according to AOSA (1990) until a constant count and final germination per cent (FGP) was calculated. Seeds were considered to have germinated after radicle emergence. The time taken to reach $50 \%$ germination $\left(\mathrm{T}_{50}\right)$ was calculated according to the formula of Coolbear et al. (1984) modified by Farooq et al. $(2005)$ : T50 $=\mathrm{ti}+[(\mathrm{N} / 2-\mathrm{ni})(\mathrm{ti}-$ $\mathrm{tj})$ ] / $\mathrm{ni}-\mathrm{nj}$. Where, $\mathrm{N}$ is the final number of emergence and ni, nj cumulative number of seeds germinated by adjacent counts at times ti and $\mathrm{tj}$, respectively when ni $<\mathrm{N} / 2<\mathrm{nj}$. Energy of germination (GE) was calculated as percentage of seeds germinated at $3^{\text {rd }}$ and $7^{\text {th }}$ day (Bam et al., 2006), respectively in okra and parsley. Seedling dry biomass (SDB) of 10 randomly selected seedlings was determined by drying the seedlings at $80 \pm 2^{\circ} \mathrm{C}$ for 48 hours. Mean germination time (MGT) was calculated according to the equation $\mathrm{MGT}=\Sigma \mathrm{Dn} / \Sigma \mathrm{n}$ (Ellis and Roberts, 1981). Where $\mathrm{n}$ is the number of seeds, which were germinated on day $\mathrm{D}$, and $\mathrm{D}$ is the number of days counted from the beginning of germination. The germination index (GI) was calculated by the equation $\mathrm{GI}=\mathrm{G} 1 / \mathrm{T} 1+\mathrm{G} 2 / \mathrm{T} 2$ $+\ldots+$ Gn / Tn (AOSA, 1983). Where, G1, G2,..., Gn: number of germinated seed on the first count, second count, and so on until the last count (n), respectively, and T1, T2,... Tn: number of days between sowing and the first count, between the sowing and the second count, and so on until the last count (n), respectively. Seedling vigour index (SVI) was calculated by multiplying the dry weight $(\mathrm{g})$ of seedlings with germination percent (Abdul-Baki and Anderson, 1973). Statistical analysis was conducted using an analysis of variance followed by Tukey's test. A $P$-value of $<0.05$ was considered significant.

\section{RESULTS AND DISCUSSION}

Hydropriming resulted in noteworthy improvements in various germination paramters of okra which also differed significantly among the assorted priming durations (Table 1). The importance of early germination, seedling emergence and rapid stand establishment and growth is quite essential to compete for water, light and nutrients. HP of Pusa sawani okra seeds for 18 hours at $25 \pm 2^{\circ} \mathrm{C}$ resulted in highest FGP $(85.7 \%)$, GE (66.5\%), GI (36.7), SDB (29.1mg) and SVI (2.49) coupled with minimum values of $\mathrm{T}_{50}(2.75$ day $)$ as well as MGT (2.38 day). The values obtained with $18 \mathrm{~h}$ HP were significantly superior $(p=0.05)$ to all other treatments. HP for 12 hours was proved as the second best treatment in terms of FGP, $\left.\mathrm{T}_{50}, \mathrm{GE}, \mathrm{MGT}, \mathrm{SDB}\right)$ and SVI, however, the values were found at par with control $(p=0.05)$. Increased priming duration for 24 hours exhibited poorest germination ability and produced significantly minimum values of FGP $(70.8 \%)$, GE $48.8 \%$ ) SDB (19.4mg) as well as SVI (1.37) associated with greater values of $\mathrm{T}_{50}$ (3.15 day) an MGT 2.85 day).

Comparable to okra, hydropriming also improved germination potential in curly type of parsley seed and differed significantly due to duration of priming at 5

Table 1. Effect of hydropriming duration on seed germination attribute in okra

\begin{tabular}{llllllll}
\hline Treatments & FGP $(\%)$ & $\mathbf{T}_{\mathbf{5 0}}$ (day) & GE (\%) & MGT (day) & GI & SDB (mg) & VI \\
\hline Control & 76.5 & 3.10 & 55.4 & 2.85 & 31.6 & 20.8 & 1.59 \\
12 hours & 79.3 & 3.06 & 59.4 & 2.67 & 30.4 & 22.6 & 1.79 \\
18 hours & 85.7 & 2.75 & 66.5 & 2.38 & 36.7 & 29.1 & 2.49 \\
24 hours & 70.8 & 3.15 & 48.8 & 2.85 & 33.4 & 19.4 & 1.37 \\
CD $(\mathrm{p} \leq 0.05)$ & 4.3 & 0.37 & 5.3 & 0.17 & 2.5 & 3.5 & 0.32 \\
\hline
\end{tabular}

FGP - final germination; $\mathrm{T}_{50}$ - time taken to 50 per cent germination; GE - energy of germination (day $7^{\text {th }}$ ); MGT - mean germination time; GI - germination index; SDB - seedling dry biomass; SVI - seedling vigour index

Table 2. Effect of hydropriming duration on seed germination attribute in parsley.

\begin{tabular}{llllllll}
\hline Treatments & FGP $(\%)$ & $\mathbf{T}_{\mathbf{5 0}}$ (day) & GE $(\%)$ & MGT (day) & GI & SDB (mg) & VI \\
\hline Control & 70.3 & 8.1 & 41.3 & 7.5 & 9.5 & 2.13 & 0.15 \\
24 hours & 78.7 & 7.2 & 48.7 & 6.5 & 12.8 & 3.13 & 0.25 \\
48 hours & 74.0 & 7.8 & 47.1 & 6.8 & 10.5 & 2.48 & 0.18 \\
72 hours & 66.5 & 8.5 & 40.2 & 7.7 & 9.6 & 1.97 & 0.13 \\
CD $(\mathrm{p} \leq 0.05)$ & 4.82 & 0.5 & 1.2 & 0.3 & 2.0 & 0.43 & 0.06 \\
\hline
\end{tabular}

FGP - final germination; $\mathrm{T}_{50}$ - time taken to 50 per cent germination; GE - energy of germination (day $7^{\text {th }}$ ); MGT - mean germination time; GI - germination index; SDB - seedling dry biomass; SVI - seedling vigour index 
per cent level of significance (Table 2). Moreover, parsley seeds required prolonged duration of time for effective priming changes to occur in terms of seed germination potential. Seed HP for 24 hours was proved as the optimum priming duration in curly type of parsley which resulted in significantly highest FGP (78.7\%), GE (48.7\%), SDB (3.13 mg), GI (12.8) and SVI (0.25) together with minimum $\mathrm{T}_{50}(7.2$ day) and MGT (6.5 day). Increased priming durations above 24 hours (i.e. 48 and 72 hours) were however proved detrimental to seed germination ability in parsley and even gone behind the unprimed dry seeds in extreme priming duration ( 72 hours). As evident from the data, seed priming for 72 hours in fact caused seed deterioration instead of invigorations and showed statistically $(p=0.05)$ lowest FGP $(66.5 \%)$, GE (40.2\%), SDB (1.97mg), GI (9.6) as well as SVI (0.13) together with highest values of $\mathrm{T}_{50}$ (8.5 day) and MGT 7.7 day) followed in ascending order by unprimed dry seeds.

Abbasdokht et al. (2004) informed that high quality of germination in crops will result high yield. An improved germination of okra due to seed hydrationdehydration (priming) treatment has earlier been reported by Enu-Kwesi et al (1986). Abbasdokht (2011) reported that hydropriming of wheat seeds (cv. Pishtaz) for 18 hours resulted in maximum germination percent, seedling biomass, root length, shoot length, germination index and seedling vigour index as compared to unprimed and haloprimed seeds under normal as well as stress environment. Caseiro et al (2004) found that hydro priming was the most effective method for improving seed germination of onion. The improved seed germination of hydroprimed seeds may be attributed to the improved physiologically active state of pre-germinated seeds due to priming (Matsushima and Sakagami, 2013) as the metabolic process of sees related to $\alpha$-amylase activity is activated by water absorption with seed priming and the metabolic potential is preserved in the seed during the dry period after seed priming (Ando and Kobata, 2002). As such increased seedling growth with HP of seeds might be the result of increased supply of soluble sugars owing to the increase in activated $\alpha$-amylase. It has also been shown that seed priming causes metabolic changes in germinating seed, such as cell cycle related events (De Castro et al., 2000), endosperm weakening by hydrolase activities (Bradford et al., 2000) and mobilization of storage proteins (Job et al., 2000). However, positive effects of seed priming on seed invigoration depends on priming duration (Ashraf and Foolad, 2005; Ghassemi-Golezani et al., 2008b). When seeds imbibe, the water content reaches a plateau and changes little until radicle emergence (Bradford, 1986). Priming up to this point can have a positive effect, while extended priming duration will negatively affect germination in tomato.

\section{Conclusion}

These results suggest that hydropriming is a good technique for germination improvement in okra as well as in parsley but proper priming duration is a key factor to ensure optimum and speedy germination with high seedling vigor. Priming duration of 18 and 24 hours at $25 \pm 2^{\circ} \mathrm{C}$ were found optimal for enhanced and rapid seed germination with vigorous seedlings in Pusa Sawani okra and curly type of parsley, respectively. Further, increase of hydropriming duration above optimum is not only uneconomical but also has detrimental effect on germination.

\section{REFERENCES}

Abbasdokht, H. (2011). The effect of hydropriming and halopriming on germination and early growth stage of wheat (Triticum aestivum L.). Desert 16: 61-68

Abbasdokht, H., Mazaheri, D., Chaichi, M., Rahimian, H., Baghestani, M. A., Mohammad Alizadeh, H. and Sharifzadeh, F. (2004). The evaluation of redroot pigweed (Amaranthus retroflexus L.) competition at different density and different time of germination on some of agronomical traits of soybean (Glycine max L.). Desert $8,104-120$

Abdul-Baki, A.A. and Anderson, J. D. (1973). Vigour determination in soybean by multiple criteria. Crop Science, 13: 630-633

Ando, H. and Kobata, T. (2002). Effect of seed hardening on the seedling emergence and $\alpha$-amylase activity in the grains of wheat and rice sown in dry soil. Japanese Journal of Crop Science, 71(2): 220-225

AOSA (Association of Official Seed Analysts). (1983). Seed vigour testing handbook. Contribution No. 32 to the Handbook of Seed Testing Lincoln, NE

AOSA (Association of Official Seed Analysts). (1990). Rules for testing seeds. Journal of Seed Technology, 12: $1-112$

Ashraf, M. and Foolad, M.R. (2005). Pre-sowing seed treatment: A shotgun approach to improve germination, plant growth and crop yield under saline and non-saline conditions. Advances in Agron. 88:223-271

Bam, R.K., Kumaga, F.K., Ori, K. and Asiedu, E.A. (2006). Germination, vigour and dehydrogenase activity of naturally aged rice (Oryza sativa L.) seeds soaked in potassium and phosphorus. Asian Journal of Plant Sciences, 5: 948-955

Bradford, K. J. (1986). Manipulation of seed water relations via osmotic priming to improve germination under stress conditions. HortScience, 21:1105-1112

Bradford, K. J., Chen, F., Cooley, M.B. Dahal, P., Downie, B., Fukunaga, K.K., Gee, O.H. Gurusinghe, S., Mella, R.A, Nonogaki, H., Wu, C.T., Yang, H. and Yim, K.O. (2000). Gene expression prior to radicle emergence in imbibed tomato seeds, pp. 231-251. In: Black, M., Bradford K. J. and Va'zquez-Ramos J. (Eds.). Seed Biology: Advances and Applications. CABI International. Wallingford, UK

Cantliffe, D.J. (2003). Seed enhancement. ISHS Acta Horticulturae 607: IX International Symposium on Timing of Field Production in Vegetable Crops, Sao Paulo, 13 (1):34 
Caseiro, R., Bennett, M.A. and Marcos-Filho, J. (2004) Comparison of three priming techniques for onion seed lots differing in initial seed quality. Seed Sci. Technol. 32: $365-375$

Coolbear P., Francis, A. and Grierson, D. (1984). The effect of low temperature pre-sowing treatment under the germination performance and membrane integrity of artificially aged tomato seeds. J. Experimen. Botan. 35 : 1609-1617

De Castro, R.D., van Lammeren, A.A.M. Groot, S.P.C., Bino, R.J. and Hilhorst, H.W.M. (2000). Cell division and subsequent radicle protrusion in tomato seeds are inhibited by osmotic stress but DNA synthesis and formation of microtubular cytoskeleton are not. Plant Physiol. 122: 327 - 335

Duman, I. and Esiyok, D. (1998) Ekim oncesi PEG ve $\mathrm{KH}_{2} \mathrm{PO}_{4}$ uygulamalarının havuc tohumlarının çimlenme ve c1kıs oranı ile verim üzerine etkileri. Turkish Journal of Agriculture and Forestry, 22: 445-449

Ellis, R.A. and Roberts, E.H. (1981). The quantification of aging and survival in orthodox seeds. Seed Sci. Technol. 9:373-409

Enu-Kwesi L., Nwalozie M. and D. I. and Anyanwu, D.I. (1986). Effect of Pre-sowing 'hydration-dehydration' on germination, vegetative growth and fruit yield of Abelmoschus esculentus under two soil moisture regimes. Tropical Agriculture (Trinidad), 63 (3): 181-184

Farooq, M., Basra, S.M.A., Hafeez, K. and Ahmad, N. (2005). Thermal hardening: a new seed vigour enhancement tool in rice. Acta Botanica Sinica, 47: 187-193

Ghassemi-Golezani, K., Chadordooz-Zeddi, A. and Nasrollahzadeh Moghaddam, M. (2010). Effects of hydropriming duration on seedling vigour and grain yield of pinto Bean (Phaseolus vulgaris L.) cultivars. Notulae Botanicae Horti Agrobotanici Cluj., 38 (1): 109-113

Ghassemi-Golezani, K. and Mardfar, R. A. (2008). Effects of limited irrigation on growth and grain yield of common bean. J. Plant Sci. 3:230-235
Groot, S. P.C., Kieliszewska-Rokicha, B., Vermeer, E and Karssen, C.M. (1988). Gibberellin-induced hydrolysis of endosperm cell walls in gibberellin-deficient tomato seeds prior to radicle protrusion. Planta. 174:500-504

Huang, R., Sukprakarn, S., Thongket, T. and Juntakool, S. (2002). Effect of hydropriming and redrying on the germination of triploid watermelon seeds. Kasetsart $J$. (Nat. Sci.), 36: $219-224$.

Job, D., Capron, I., Job, C. Dacher, F., Corbineau, F. and Come, D (2000). Identification of germination-specific protein markers and their use in seed priming technology, pp. 449- 459. In: Black M., Bradford K. J. and Va'zquez-Ramos J. (Eds.). Seed Biology: Advances and Applications. CAB International. Wallingford, UK.

Khafagy, M.A., Darowish, M.M., Salama, S.M. and Abo-E1Kheer, E.A.M. (2014). Effect of water priming duration on rice (Oryza sativa L.) germination and seedling growth under ISO-osmotic solution of $\mathrm{NaCl}$ and PEG. J. Plant Production, Mansoura Univ., 5(12):2141 -2157

Matsushima K and Sakagami J. (2013). Effects of seed hydropriming on germination and seedling vigor during emergence of rice under different soil moisture conditions. American Journal of Plant Sciences, 4: 15841593

Mc-Donald, M.B. (1999). Seed deterioration: Physiology, repair and assessment. Journal of Seed Science Technology 27: 177-273.

Ogbuehi, H.C., Madukwe, D.K. and Ashilonu, P. (2013). Assessment of hydropriming of seeds on performance of morphological indices of bambara groundnut (Vigna subterrenealinn) landrace. G.J B.A.H.S., 2(2):17-22

Pandita, V.K., Anand, A., Nagarajan, S., Seth, R., Sinha, S.N. (2010). Solid matrix priming improves seed emergence and crop performance in okra, Seed Science and Technology, 38: 665-674

Vural, H., Eşiyok, D. and Duman, I. (2000). Cultural vegetables, [Kültür sebzeleri (sebze yetiştirme)] Ege University Publications. 166. ISBN: 975-97190-0-2 